\title{
Article
}

\section{Analysis of Biomechanical Parameters of Muscle Soleus Contraction and Blood Biochemical Parameters in Rat with Chronic Glyphosate Intoxication and Therapeutic Use of $\mathrm{C}_{60}$ Fullerene}

\author{
Dmytro Nozdrenko ${ }^{1}$, Olga Abramchuk ${ }^{2}$, Svitlana Prylutska ${ }^{1,3}$, Oksana Vygovska ${ }^{4}$, Vasil Soroca ${ }^{1}$, \\ Kateryna Bogutska ${ }^{1}\left(\mathbb{D}\right.$, Sergii Khrapatyi ${ }^{5}$, Yuriy Prylutskyy ${ }^{1}$, Peter Scharff ${ }^{6}$ and Uwe Ritter ${ }^{6, *(\mathbb{D}}$
}

check for updates

Citation: Nozdrenko, D.;

Abramchuk, O.; Prylutska, S.; Vygovska, O.; Soroca, V.; Bogutska, K.; Khrapatyi, S.; Prylutskyy, Y.; Scharff, P.; Ritter, U. Analysis of Biomechanical Parameters of Muscle Soleus Contraction and Blood Biochemical Parameters in Rat with Chronic Glyphosate Intoxication and Therapeutic Use of $\mathrm{C}_{60}$ Fullerene. Int. J. Mol. Sci. 2021, 22, 4977. https:// doi.org/10.3390/ijms22094977

Academic Editor: Ana

María Díez-Pascual

Received: 29 March 2021

Accepted: 5 May 2021

Published: 7 May 2021

Publisher's Note: MDPI stays neutral with regard to jurisdictional claims in published maps and institutional affiliations.

Copyright: (c) 2021 by the authors Licensee MDPI, Basel, Switzerland. This article is an open access article distributed under the terms and conditions of the Creative Commons Attribution (CC BY) license (https:// creativecommons.org/licenses/by/ $4.0 /)$.
1 Department of Biophysics and Medical Informatic, Taras Shevchenko National University of Kyiv, 01601 Kyiv, Ukraine; ddd@univ.kiev.ua (D.N.); psvit_1977@ukr.net (S.P.); vmsoroka@gmail.com (V.S.); bogutska_ki@knu.ua (K.B.); prylut@ukr.net (Y.P.)

2 Lesya Ukrainka Volyn National University, 43025 Lutsk, Ukraine; Abramchuk.Olga@vnu.edu.ua National University of Life and Environmental Science of Ukraine, 03041 Kyiv, Ukraine

Bogomolets National Medical University of Kyiv, 01601 Kyiv, Ukraine; ovvigovskaya@gmail.com Interregional Academy of Personnel Management, 03039 Kyiv, Ukraine; khrapatiysv@gmail.com

6 Institute of Chemistry and Biotechnology, Technical University of Ilmenau, 98693 Ilmenau, Germany; peter.scharff@tu-ilmenau.de

* Correspondence: uwe.ritter@tu-ilmenau.de

\begin{abstract}
The widespread use of glyphosate as a herbicide in agriculture can lead to the presence of its residues and metabolites in food for human consumption and thus pose a threat to human health. It has been found that glyphosate reduces energy metabolism in the brain, its amount increases in white muscle fibers. At the same time, the effect of chronic use of glyphosate on the dynamic properties of skeletal muscles remains practically unexplored. The selected biomechanical parameters (the integrated power of muscle contraction, the time of reaching the muscle contraction force its maximum value and the reduction of the force response by $50 \%$ and $25 \%$ of the initial values during stimulation) of muscle soleus contraction in rats, as well as blood biochemical parameters (the levels of creatinine, creatine phosphokinase, lactate, lactate dehydrogenase, thiobarbituric acid reactive substances, hydrogen peroxide, reduced glutathione and catalase) were analyzed after chronic glyphosate intoxication (oral administration at a dose of $10 \mu \mathrm{g} / \mathrm{kg}$ of animal weight) for 30 days. Water-soluble $\mathrm{C}_{60}$ fullerene, as a poweful antioxidant, was used as a therapeutic nanoagent throughout the entire period of intoxication with the above herbicide (oral administration at doses of 0.5 or $1 \mathrm{mg} / \mathrm{kg}$ ). The data obtained show that the introduction of $\mathrm{C}_{60}$ fullerene at a dose of $0.5 \mathrm{mg} / \mathrm{kg}$ reduces the degree of pathological changes by $40-45 \%$. Increasing the dose of $\mathrm{C}_{60}$ fullerene to $1 \mathrm{mg} / \mathrm{kg}$ increases the therapeutic effect by 55-65\%, normalizing the studied biomechanical and biochemical parameters. Thus, $\mathrm{C}_{60}$ fullerenes can be effective nanotherapeutics in the treatment of glyphosate-based herbicide poisoning.
\end{abstract}

Keywords: glyphosate; $\mathrm{C}_{60}$ fullerene; muscle soleus of rat; biomechanical parameters; blood biochemical parameters

\section{Introduction}

Glyphosate (N-(phosphonomethyl) glycine) is a non-selective herbicide most commonly used for weed control. Among herbicides, it ranks first in the world in production. Many agricultural crops are genetically engineered to tolerate glyphosate. This significantly increases the effectiveness of weed control in these crops. The effect of glyphosate on a plant is due to the fact that it inhibits the components of the enzyme system of the shikimate pathway of biosynthesis of benzoic aromatic compounds [1]. Animals do not have such 
an enzyme system and therefore this herbicide is considered to be relatively harmless to them. The half-lethal dose $\left(\mathrm{LD}_{50}\right)$ of glyphosate is $>5 \mathrm{~kg} / \mathrm{kg}$ of rat body weight with a single administration [1].

In recent years, there has been a growing worldwide concern about the possible direct and indirect health effects of the widespread use of glyphosate. In 2015, the World Health Organization reclassified glyphosate as likely carcinogenic to humans [2]. There is considerable controversy regarding its carcinogenicity and toxicity, with very different opinions of the scientists and regulatory bodies involved in the glyphosate study. One of the key aspects of this controversy is the extent of pathological changes in laboratory animals that are caused by glyphosate [3]. The most convincing data indicate that glyphosate causes hemangiosarcomas, tumors and malignant lymphomas, renal and liver adenomas, nervous and miotic disorders of a wide spectrum of severity [3].

Glyphosate also causes numerous morphological, physiological and biochemical disorders in the cells and organs of animals, including mammals. It worsens the condition of the gastrointestinal tract: a violation of its contractile function is observed already at a concentration of $3 \mathrm{mg} / \mathrm{L}$; the violation of motility continues after the removal of glyphosate from the incubation solution [4]. The use of glyphosate as a herbicide in agriculture can lead to the presence of its residues and metabolites (aminomethylphosphonic acid) in food for human consumption and thus pose a threat to human health. The authors [5] found that glyphosate reduces energy metabolism in the brain, its amount increases in white muscle fibers.

At the same time, the effect of chronic use of glyphosate on the dynamic properties of skeletal muscles remains practically unexplored. It was shown that the activity of acetylcholinesterase (AChE) did not change in the muscles and brain of animals exposed to glyphosate during the first $96 \mathrm{~h}$. On the contrary, the expression of this enzyme in muscle tissue changed [6]. The consequence of these pathological processes is disorders in the dynamics of contraction of the muscular system of varying severity. The results [7] show that glyphosate intoxication increases energy expenditure to maintain homeostasis. In particular, there was a decrease in the level of glycogen and triglycerides in all organs and an increase in lipid peroxidation (LPO).

The mechanisms for the toxicity of glyphosate-based drugs are complex. It is difficult to separate the toxicity of glyphosate from the toxicity of the drug as a whole, or to determine the contribution of surfactants to the overall toxicity. As a result, the treatment of poisoning occurs for a long time, symptomatic and ineffective [8].

Studies of the effect of a glyphosate-based herbicide on AChE enzyme activity and oxidative stress at concentrations of $0.5-10.0 \mathrm{mg} / \mathrm{L}$ for $96 \mathrm{~h}$ followed by an equal recovery period indicate the presence of LPO and AChE inhibition. The results also showed an increased level of thiobarbituric acid reactive substances (TBARS) at all tested herbicide concentrations, which remained elevated even after a recovery period [9]. According to the authors, the triggering mechanisms of the onset of these pathological cascades are associated precisely with the formation of a large number of free radicals. They initiate LPO, cause direct inhibition of mitochondrial enzymes of the respiratory chain and their ATPase activity, inactivation of glyceraldehyde 3-phosphate dehydrogenase and membrane sodium channels.

The ability of $C_{60}$ fullerenes to inactivate free radicals was described back in 1991 [10]. One $\mathrm{C}_{60}$ molecule simultaneously captures 34 methyl radicals, effectively inactivates the superoxide anion radical and hydroxyl radicals in vitro system, protecting cell membranes from oxidation [11]. It is assumed that biocompatible and water-soluble $\mathrm{C}_{60}$ fullerenes [12] can be considered as powerful scavengers of free radicals during the development of ischemia and fatigue processes in skeletal muscle [13,14]. In our previous works on in vivo models, it was shown that the usage of safe doses of water-soluble $\mathrm{C}_{60}$ fullerene at the initiation of various pathologies leads to significant positive therapeutic effects, in particular, during acute liver injury, colorectal cancer, obesity, acute cholangitis and hemiparkinsonism [15-20]. 
Based on the above data, the purpose of this work was to estimate the therapeutic effect of water-soluble $\mathrm{C}_{60}$ fullerene, as a powerful antioxidant, on the development of muscle pathologies in rat skeletal muscle caused by chronic glyphosate intoxication.

\section{Results and Discussion}

\subsection{AFM Analysis}

It is known that the size of $\mathrm{C}_{60}$ fullerene particles in aqueous solution strongly correlates with their specific biological properties and toxicity. So, the antibacterial activity of $C_{60}$ fullerene is connected with its ability to undergo aggregation [21]; the macrophage apoptosis induced by aqueous $\mathrm{C}_{60}$ fullerene aggregates changes the mitochondrial membrane potential [22]; the respiratory toxicity and immunotoxicity of $\mathrm{C}_{60}$ fullerenes in mice and rats after nose inhalation strictly depends on their nano- and micro-size [23]; depending on the size $\mathrm{C}_{60}$ fullerenes can inhibit $\mathrm{BK}_{\mathrm{Ca}}$ but not $\mathrm{K}_{\mathrm{v}}$ channels in pulmonary artery smooth muscle cells [24], penetrate through plasma membrane inside the cell [25] or be adsorbed on the surface of the membrane [26]. Therefore, the size effect of $\mathrm{C}_{60}$ fullerene particles in aqueous solution is considered now to be very important.

The atomic force microscopy (AFM) study of $\mathrm{C}_{60}$ fullerene films deposited from an aqueous solution revealed a high degree of molecules dispersion in solution. It turned out that $\mathrm{C}_{60}$ fullerene aqueous solution $\left(\mathrm{C}_{60} \mathrm{FAS}\right)$ contains both single $\mathrm{C}_{60}$ fullerene (see the objects with a height of $\sim 0.7 \mathrm{~nm}$ in Figure 1a) and its labile nanoaggregates (objects with a height of 1.4-60 nm in Figure $1 \mathrm{~b}$ ). The majority of $\mathrm{C}_{60}$ molecules were located chaotically and separately along the surface, or in the form of bulk clusters. Thus, $\mathrm{C}_{60} \mathrm{FAS}$ is a polydisperse colloid nanofluid. This result is in a good agreement with our previous probe microscopic data $[27,28]$.
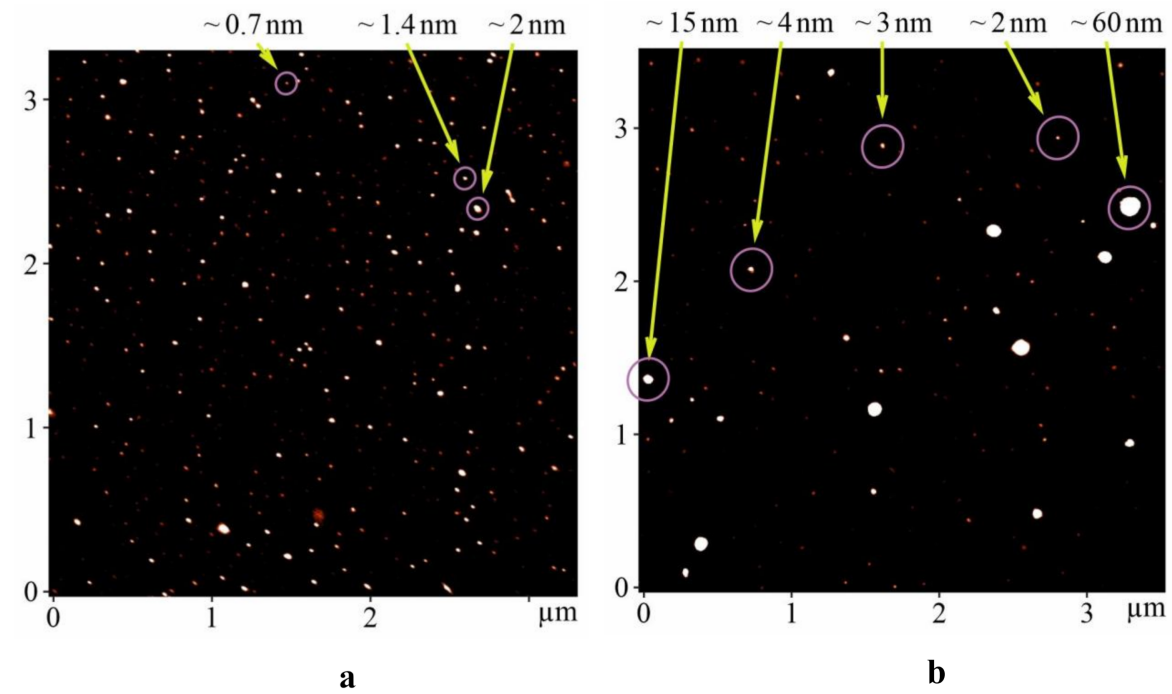

Figure 1. AFM images (tapping mode) of $C_{60}$ fullerene nanoparticles on the mica surface (concentration $0.15 \mathrm{mg} / \mathrm{mL}$ ) (a) objects with a height of $\sim 0.7 \mathrm{~nm}(\mathbf{b})$ objects with a height of $1.4-60 \mathrm{~nm}$.

In addition, the stability of the used $\mathrm{C}_{60}$ FAS was evaluated by the zeta potential measurement. This value was shown to be $-30.3 \mathrm{mV}$ at room temperature. Such a high (by absolute value) zeta potential for the $\mathrm{C}_{60} \mathrm{FAS}$ indicates its high stability (low tendency for nanoparticle aggregation over time) and suitability for further biological research.

\subsection{Biomechanical Analysis}

In the process of analysis of the force curves obtained during stimulation of muscle soleus by $5 \mathrm{~s}$ pools for $1500 \mathrm{~s}$ after chronic intoxication of animals with glyphosate for 30 days, serious disorders in muscle dynamics are visible (Figure 2). The integrated power of muscle contraction during the whole period of stimulation decreased to $41 \pm 3 \%$ of the 
control values (Figure 3). A significant reduction in the force response ended in complete muscle rigidity after $1200 \mathrm{~s}$. However, in animals treated with $\mathrm{C}_{60} \mathrm{FAS}$, this parameter was $57 \pm 2 \%$ and $68 \pm 4 \%$ at doses of $C_{60}$ fullerene 0.5 and $1 \mathrm{mg} / \mathrm{kg}$, respectively. It should be noted that in this case, the muscle responded with a contractile response throughout the stimulation period, not falling below $30 \%$ of the limit (Figures 2 and 3). The time of reduction of the force response by $50 \%$ and $25 \%$ from the initial values increased from $103 \pm 11 \mathrm{~s}$ and $790 \pm 17 \mathrm{~s}$ after glyphosate poisoning to $760 \pm 8 \mathrm{~s}$ and $1213 \pm 14 \mathrm{~s}$ and $940 \pm 21 \mathrm{~s}$ and $1820 \pm 24 \mathrm{~s}$ after therapeutic use of $\mathrm{C}_{60} \mathrm{FAS}$ at doses of 0.5 and $1 \mathrm{mg} / \mathrm{kg}$, respectively. The maximum and minimum recorded forces of muscle contraction throughout stimulation were $0.81 \pm 0.10 \mathrm{~N}$ and $0.30 \pm 0.05 \mathrm{~N}$ after glyphosate poisoning, $1.65 \pm 0.20 \mathrm{~N}$ and $1.72 \pm 0.20 \mathrm{~N}$ and $2.67 \pm 0.30 \mathrm{~N}$ and $2.93 \pm 0.30 \mathrm{~N}$ after therapeutic use of $\mathrm{C}_{60} \mathrm{FAS}$ at doses of 0.5 and $1 \mathrm{mg} / \mathrm{kg}$, respectively (Figures 2 and 3).

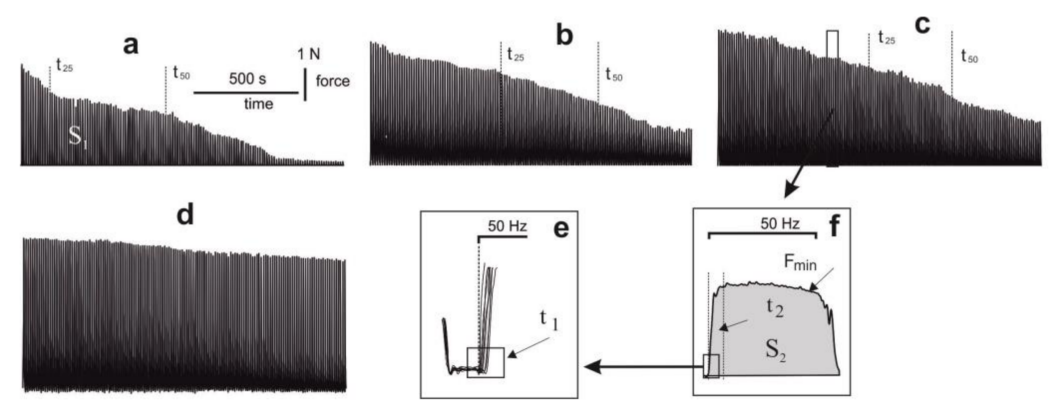

Figure 2. Curves of the generation of the contraction force of muscle soleus rat after chronic intoxication with glyphosate for 30 days: (a), (b), (c) and (d) - the curves of muscle contraction for $1500 \mathrm{~s}$ with the administration to the animals of glyphosate, glyphosate and $\mathrm{C}_{60} \mathrm{FAS}$ at doses of 0.5 and $1 \mathrm{mg} / \mathrm{kg}$, respectively, and with the administration to the animals of distilled water (control group); (e) mechanograms of single contractions; (f) an example of calculating the time of the onset of a muscle response. $S_{1}$ is the integrated power of muscle contraction throughout the entire period of stimulation; $S_{2}$ is the integrated power in a single contraction; $F_{\min }$ is the minimum value of force generation in a single contraction; $\mathrm{t}_{50}$ and $\mathrm{t}_{25}$ are the time of decreasing the maximum force response to $50 \%$ and $25 \%$ of the initial amplitude of muscle force; $t_{1}$ and $t_{2}$ are the time of the onset of the muscle response and the force reaching its maximum value in a single contraction.

a

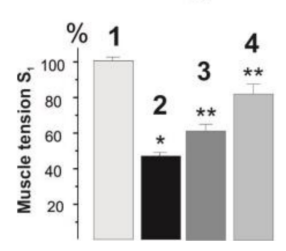

b

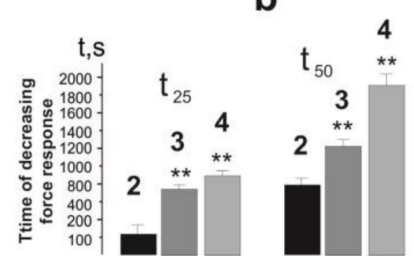

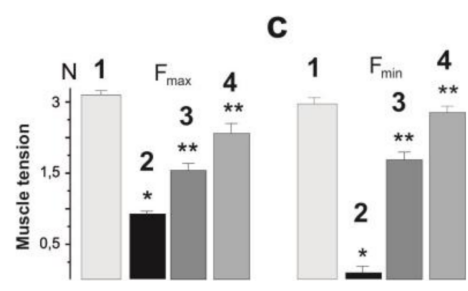

Figure 3. Parameters of contractile activity of muscle soleus rat after chronic intoxication with glyphosate for 30 days: (a) integrated power of muscle contraction throughout the entire period of stimulation $\left(\mathrm{S}_{1}\right)$, presented as a percentage of control values; (b) time of decreasing the force response by $50 \%\left(\mathrm{t}_{50}\right)$ and $25 \%\left(\mathrm{t}_{25}\right)$ from the initial values; (c) maximum ( $\left.\mathrm{F}_{\max }\right)$ and minimum $\left(\mathrm{F}_{\mathrm{min}}\right)$ fixed forces of muscle contraction throughout the entire duration of stimulation. 1-control group (native muscle); 2 - the glyphosate group; 3 - the glyphosate $+C_{60}$ fullerene $(0.5 \mathrm{mg} / \mathrm{kg})$ group; 4 - the glyphosate $+C_{60}$ fullerene $(1 \mathrm{mg} / \mathrm{kg})$ group; ${ }^{*} p<0.05$ relative to the control group; ${ }^{* *} p<0.05$ relative to the glyphosate group.

A decrease in the strength activity of a muscle during glyphosate poisoning can be explained by a violation of energy metabolism. So, in a study [29], the authors found that a high concentration of the herbicide led to a significant decrease in the energy reserve in the muscles, showing an unfavorable sublethal effect on energy metabolism and, consequently, on the dynamic properties of the muscular system in general. The recorded significant positive therapeutic effect of $\mathrm{C}_{60}$ fullerene may be associated exclusively with its antioxidant 
properties, which reduce the degree of damage to cell membranes. To confirm this, we analyzed the biomechanical parameters of single muscle contractions (Figure 4).
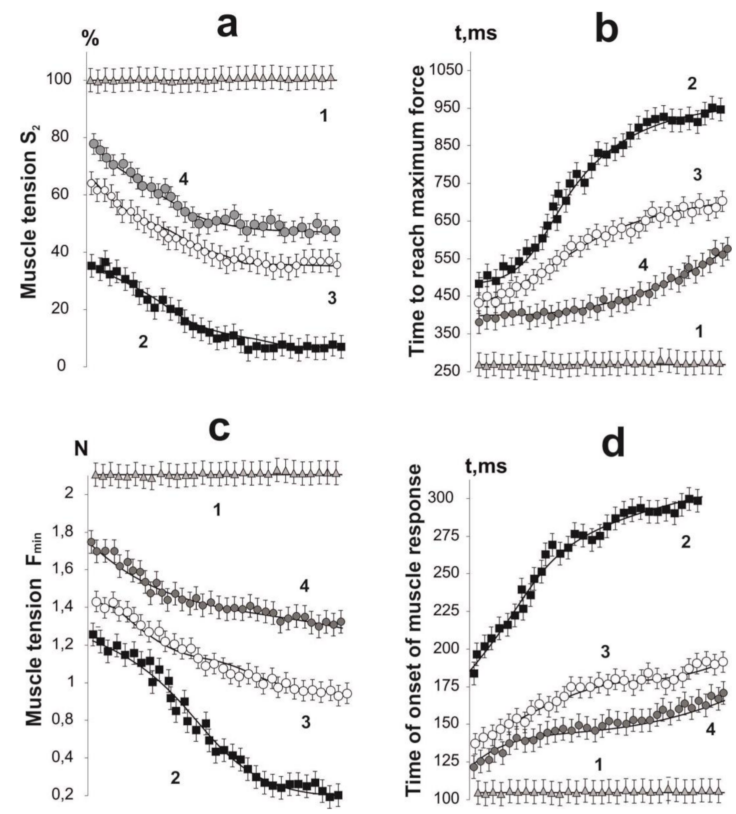

Figure 4. Parameters of single contractions of muscle soleus rat after chronic intoxication with glyphosate for 30 days, caused by 5 s stimulation with a frequency of $50 \mathrm{~Hz}$ : (a) integrated muscle power $\left(\mathrm{S}_{2}\right)$, calculated from the total area of the force curves as a percentage of the control values; (b) time to reach the maximum force response; $(c)$ minimum $\left(\mathrm{F}_{\mathrm{min}}\right)$ fixed force of muscle contraction; (d) time of onset of muscle response to stimulation. 1-control group (native muscle); 2-the glyphosate group; 3-the glyphosate $+\mathrm{C}_{60}$ fullerene $(0.5 \mathrm{mg} / \mathrm{kg})$ group; 4 - the glyphosate $+\mathrm{C}_{60}$ fullerene $(1 \mathrm{mg} / \mathrm{kg})$ group.

The dynamics of the contractile component is determined by the sensitive mechanisms of interaction of motor neuron pools with actin and myosin myofilaments. The influence of pathological factors on these processes leads either to a complete dysfunction of this process, or to its desynchronization. As a result, the whole muscle, as a dynamic system, is unable to adequately implement the pools of neural activity coming from the central nervous system (CNS). The nature and level of such dysfunctions is directly related to the level of development of pathological processes in both muscle and nervous tissue. The results of studies [30] show that the effect of the glyphosate-based herbicide affects the CNS of rats, possibly altering the neurotransmitter systems that regulate locomotor activity.

The experiment made it possible to trace the therapeutic effect of $\mathrm{C}_{60} \mathrm{FAS}$ on different regions of the generation of the force response of the rat muscle after chronic intoxication with glyphosate (Figure 4). A change in the time the force reaches its maximum level is one of the most important parameters of the kinetics of skeletal muscle contraction. This component of muscle dynamics is especially important in controlling hand contraction in humans. Pathological processes occurring in the nervous or muscle tissue lead to its increase, which complicates, and in some cases completely blocks the possibility of accurate positioning of the joint with the damaged muscle [31]. After taking glyphosate for 30 days, this parameter increased significantly. It should be noted that this increase was progressive with growing in the number of contractions: from $470 \pm 27 \mathrm{~ms}$ with the first contraction to $954 \pm 33 \mathrm{~ms}$ with the last contraction (in control, $250 \pm 11 \mathrm{~ms}$ ). These values changed significantly after the therapeutic use of $\mathrm{C}_{60} \mathrm{FAS}$ : with a dose of $\mathrm{C}_{60}$ fullerene of $0.5 \mathrm{mg} / \mathrm{kg}$, this time was $430 \pm 22 \mathrm{~ms}$ and $650 \pm 29 \mathrm{~ms}$, respectively, and with a dose of $1 \mathrm{mg} / \mathrm{kg}$ $367 \pm 19 \mathrm{~ms}$ and $543 \pm 24 \mathrm{~ms}$, respectively (Figure 4). Thus, the protective effect of $\mathrm{C}_{60} \mathrm{FAS}$ was more than $30 \%$ in the first and more than $65 \%$ in the second cases. 
To understand the features of muscle dynamics during the development of a pathological process, it is important to analyze the rate of processing of stimulation pools emanating from the CNS into the mechanical component of contraction and the possibility of modifying the kinetics of contraction under the influence of pathological changes. A change in the time of the onset of muscle response after nerve stimulation is one of the most important parameters of the kinetics of skeletal muscle contraction. Analysis of the data obtained showed a significant increase in this parameter after glyphosate poisoning from $175 \pm 22 \mathrm{~ms}$ with the first contraction to $298 \pm 27 \mathrm{~ms}$ with the last compared with the control-102 $\pm 8 \mathrm{~ms}$. $\mathrm{C}_{60} \mathrm{FAS}$ therapy at a dose of $\mathrm{C}_{60}$ fullerene $0.5 \mathrm{mg} / \mathrm{kg}$ reduced this time to $132 \pm 19 \mathrm{~ms}$ and $184 \pm 17 \mathrm{~ms}$ during the first and last muscle contractions, respectively, and with a dose of $C_{60}$ fullerene $1 \mathrm{mg} / \mathrm{kg}$ - to $120 \pm 20 \mathrm{~ms}$ and $165 \pm 14 \mathrm{~ms}$, respectively. It should be noted that significant decrease in this indicator under the action of both doses of $\mathrm{C}_{60}$ fullerene (Figure 4): the protective effect of $\mathrm{C}_{60} \mathrm{FAS}$ was more than $65 \%$ in the first case and more than $75 \%$ in the second case.

A change in the level of minimum force of muscle contraction generation is an indicator of significant changes caused by pathological processes in the myocyte. This indicator is not associated with neuropathic damage and its analysis gives an idea of violations of the force generation system within the muscle fiber. When performing fairly simple single-joint movements, this marker is the main indicator of muscle dysfunction, the phenomenological analysis of which makes it possible to establish the presence of causal relationships between the levels of decrease in the biomechanical activity of muscles and the development of the pathological process [32]. With a constant level of the minimum force of more than $2 \mathrm{~N}$ in the control, its drop with the use of glyphosate ranged from $1.3 \pm 0.1 \mathrm{~N}$ to zero. $\mathrm{C}_{60} \mathrm{FAS}$ therapy increased the level of the minimum force of muscle contraction to (1.4-0.9) $\pm 0.1 \mathrm{~N}$ at a dose of $\mathrm{C}_{60}$ fullerene $0.5 \mathrm{mg} / \mathrm{kg}$ and up to (1.7-1.4) $\pm 0.1 \mathrm{~N}$ at a dose of $\mathrm{C}_{60}$ fullerene $1 \mathrm{mg} / \mathrm{kg}$, respectively. In this case, the protective effect of $\mathrm{C}_{60} \mathrm{FAS}$ was more than $50 \%$ in the first case and more than $75 \%$ in the second case.

All these changes ultimately lead to a change in the overall strength activity of the muscle, which can be quantified by the value of the integrated power. A change in this parameter can be associated with disorder in both neural component and muscular component of the studied pathology [33]. With chronic use of glyphosate, the integrated power decreased from $41 \pm 3 \%$ to zero. $\mathrm{C}_{60} \mathrm{FAS}$ therapy brought this level to $63 \pm 3 \%-47$ $\pm 5 \%$ at a dose of $\mathrm{C}_{60}$ fullerene $0.5 \mathrm{mg} / \mathrm{kg}$ and $80 \pm 6 \%-54 \pm 2 \%$ at a dose of $\mathrm{C}_{60}$ fullerene of $1 \mathrm{mg} / \mathrm{kg}$, respectively. The protective effect of $\mathrm{C}_{60} \mathrm{FAS}$ was more than $50 \%$ in the first case and more than $60 \%$ in the second case.

\subsection{Biochemical Analysis}

Analysis of biochemical markers of rat blood, in particular creatinine, creatine phosphokinase (CPK), lactate (LA) and lactate dehydrogenase (LDH), makes it possible to assess the physiological changes occurring in skeletal muscle and the effect of a therapeutic drug on pathological processes in it. Studies have shown that the levels of the selected markers have a pronounced tendency to increase in the blood of rats intoxicated with glyphosate and decrease during $\mathrm{C}_{60}$ FAS therapy (Figure 5).
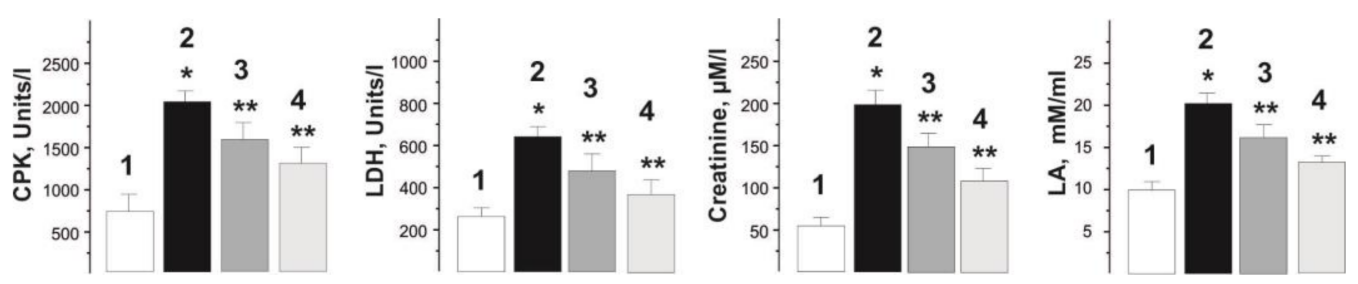

Figure 5. Biochemical parameters of rat blood (CPK, LDH, creatinine and LA) after chronic glyphosate intoxication for 30 days. 1 - control group (native muscle); 2 - the glyphosate group; 3 - the glyphosate $+\mathrm{C}_{60}$ fullerene $(0.5 \mathrm{mg} / \mathrm{kg}) \mathrm{group}$; 4 - the glyphosate $+C_{60}$ fullerene $(1 \mathrm{mg} / \mathrm{kg})$ group; ${ }^{*} p<0.05$ relative to the control group; ${ }^{* *} p<0.05$ relative to the glyphosate group. 
The change in the concentration of CPK, an enzyme from the energy supply system of musculoskeletal cells, from $756 \pm 26 \mathrm{U} / \mathrm{L}$ in the norm to $1950 \pm 33 \mathrm{U} / \mathrm{L}$ after glyphosate intoxication, in our opinion, may be the result of destruction of myocyte walls caused by the influence of the herbicide, with partial release of intramyocytic enzymes into the extracellular space. With the use of $\mathrm{C}_{60} \mathrm{FAS}$, the CPK level decreased by $23.2 \pm 3 \%$ and $31.7 \pm 2 \%$ at doses of $C_{60}$ fullerene 0.5 and $1 \mathrm{mg} / \mathrm{kg}$, respectively (Figure 5).

Analysis of changes in the level of LDH made it possible to assess the overall health of the injured muscle. The increase in the LDH level after administration of glyphosate increased from $254 \pm 13 \mathrm{U} / \mathrm{L}$ (normal) to $659 \pm 26 \mathrm{U} / \mathrm{L}$ and is evidence of the development of significant dysfunctions of the neuromuscular drug and, as a consequence, the development of fatigue processes. After therapeutic use of $\mathrm{C}_{60} \mathrm{FAS}$, the LDH level decreased by $27 \pm 3 \%$ and $31 \pm 2 \%$ at doses of $\mathrm{C}_{60}$ fullerene 0.5 and $1 \mathrm{mg} / \mathrm{kg}$, respectively.

The change in creatinine level from $50 \pm 2 \mu \mathrm{M} / \mathrm{L}$ in the control to $196 \pm 4 \mu \mathrm{M} / \mathrm{L}$ with chronic intake of glyphosate confirms previously obtained data that increased serum creatinine level is an important factor for predicting the severity of glyphosate poisoning [34]. $\mathrm{C}_{60}$ FAS therapy led to a significant decrease in its levels to $157 \pm 3 \mu \mathrm{M} / \mathrm{L}$ and $112 \pm 4 \mu \mathrm{M} / \mathrm{L}$ at doses of $\mathrm{C}_{60}$ fullerene 0.5 and $1 \mathrm{mg} / \mathrm{kg}$, respectively. In our opinion, the decrease in the creatinine fraction in this case is caused by the antioxidant properties of $\mathrm{C}_{60}$ fullerene, its ability to reduce inflammatory reactions and protect the membranes of skeletal muscle cells from nonspecific free radical destruction by efficient absorption of free radicals [35].

Contraction of skeletal muscles leads to the accumulation of LA and $\mathrm{H}^{+}$ions and, accordingly, to acidification of the intra- and extracellular media, which reduces the production of ATP and suppresses the activity of $\mathrm{Na}^{+}, \mathrm{K}^{+}$-ATPase. This leads to a delay in the generation of action potentials and reduces muscle activity. Pathological processes in the myocyte increase this imbalance towards acidification of the medium and, thus, the LA level is an important marker for assessing the degree of muscle activity. Analysis of the LA level showed its increase from $10 \pm 1 \mathrm{mM} / \mathrm{mL}$ (normal) to $19 \pm 2 \mathrm{mM} / \mathrm{mL}$ after using glyphosate. The use of $\mathrm{C}_{60} \mathrm{FAS}$ therapy reduced its level to $16 \pm 2 \mathrm{mM} / \mathrm{mL}$ and $14 \pm 1 \mathrm{mM} / \mathrm{mL}$ at doses of $C_{60}$ fullerene 0.5 and $1 \mathrm{mg} / \mathrm{kg}$, respectively.

Glyphosate is an endocrine disruptor in chronic ingestion, exhibiting high cytotoxicity. The previously obtained results [36] show that it affects survival due to deregulation of the cell cycle and metabolic changes that can alter mitochondrial oxygen consumption, increase free radical levels, damage DNA, cause hypoxia, accumulation of mutations and, ultimately, cell death. It was also shown that after exposure to the herbicide for 8 days at a concentration of $0.95 \mathrm{mg} / \mathrm{L}$, there was an increase in the amount of TBARS in muscle and brain tissues. An increase in reduced glutathione (GSH) level also indicated a compensatory response of the body against toxic conditions. Oxidative stress that arose during the period of exposure to the herbicide was probably caused by increased LPO [30]. Thus, a change in the level of endogenous antioxidants is an important marker that determines the degree of physiological disorders in muscle cells during glyphosate intoxication.

Figure 6 shows the results of measurements of indicators of pro- and antioxidant balance in the blood of experimental rats. The data obtained indicate increased levels of peroxidation and oxidative stress as well as endogenous antioxidants with the use of the herbicide. The increase in these biochemical markers compared to control values was $218 \pm 19 \%, 251 \pm 14 \%, 280 \pm 19 \%$ and $250 \pm 24 \%$ for TBARS, hydrogen peroxide $\left(\mathrm{H}_{2} \mathrm{O}_{2}\right)$, GSH and catalase (CAT) activity, respectively.

The level of these markers decreased significantly after therapeutic use of $\mathrm{C}_{60} \mathrm{FAS}$. So, the TBARS level decreased to $170 \pm 11 \%$ and $120 \pm 8 \%$ of the control values, $\mathrm{H}_{2} \mathrm{O}_{2}-160 \pm$ $14 \%$ and $114 \pm 11 \%$, GSH $-150 \pm 12 \%$ and $128 \pm 9 \%$, CAT activity- $140 \pm 14 \%$ and $119 \pm$ $10 \%$ at doses of $\mathrm{C}_{60}$ fullerene 0.5 and $1 \mathrm{mg} / \mathrm{kg}$, respectively. 


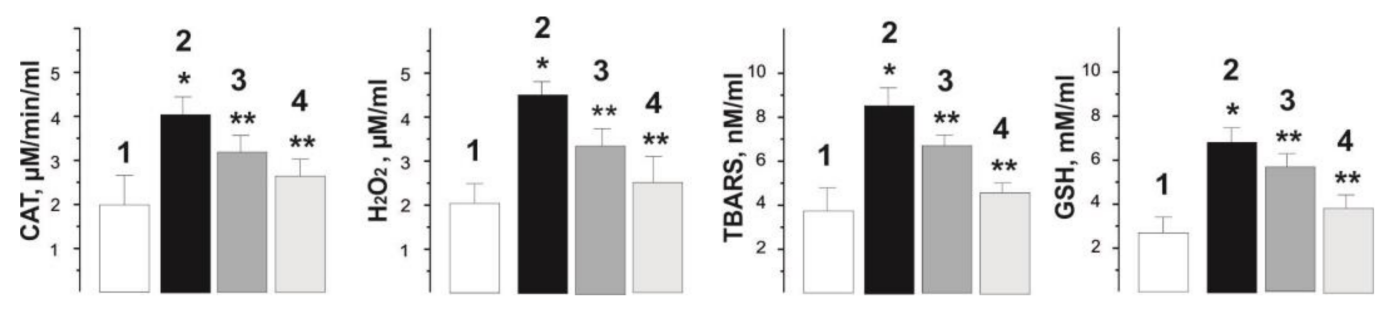

Figure 6. Indicators of pro- and antioxidant balance (CAT, $\mathrm{H}_{2} \mathrm{O}_{2}$, TBARS and GSH) in the blood of rats after chronic intoxication with glyphosate for 30 days. 1 - control group (native muscle); 2 - the glyphosate group; 3 -the glyphosate $+\mathrm{C}_{60}$ fullerene $(0.5 \mathrm{mg} / \mathrm{kg})$ group; 4 - the glyphosate $+\mathrm{C}_{60}$ fullerene $(1 \mathrm{mg} / \mathrm{kg})$ group; ${ }^{*} p<0.05$ relative to the control group; ** $p<0.05$ relative to the glyphosate group.

Summarizing, the proposed therapy with the use of low doses of water-soluble $\mathrm{C}_{60}$ fullerenes, possessing membranotropic [25,37] and powerful antioxidant properties [38], leads to positive biomechanical and biochemical changes in the character of contractile processes in the skeletal muscles of rats with chronic glyphosate intoxication.

\section{Materials and Methods}

To obtain $\mathrm{C}_{60} \mathrm{FAS}$ (maximum concentration $0.15 \mathrm{mg} / \mathrm{mL}$ ), a method based on the transfer of these carbon molecules from toluene to water followed by sonication was used $[27,39]$. The prepared $\mathrm{C}_{60}$ FAS was stored at a temperature of $+4{ }^{\circ} \mathrm{C}$ for 12 months.

The AFM (Solver Pro M system, NT-MDT, Moscow, Russia) was performed to determine the size of $\mathrm{C}_{60}$ fullerene particles in the prepared aqueous solution. A drop of investigated solution was transferred on the atomic-smooth substrate to deposit layers. Measurements were carried out after complete evaporation of the solvent. For AFM study, a freshly broken surface of mica (SPI supplies, V-1 grade) was used as a substrate. Measurements were carried out in a semicontact (tapping) mode with AFM probes of the RTPESPA150 (Bruker, $6 \mathrm{~N} / \mathrm{m}, 150 \mathrm{kHz}$ ) type.

The zeta potential was measured to assess the stability of the prepared $\mathrm{C}_{60} \mathrm{FAS}$ using the Zetasizer Nano-ZS90 technique (Malvern, Worcestershire, UK).

The experiments were performed on male Wistar rats aged 3 months weighing 170 $\pm 5 \mathrm{~g}$. The study protocol was approved by the bioethics committee of Taras Shevchenko National University of Kyiv in accordance with the rules of the European Convention for the Protection of Vertebrate Animals Used for Experimental and Other Scientific Purposes and the norms of biomedical ethics in accordance with the Law Of Ukraine №3446-IV 21.02.2006, Kyiv, on the Protection of Animals from Cruelty during medical and biological research.

In total, 40 rats divided into four groups (10 animals each) were used in the study. Glyphosate was administered daily at a dose of $10 \mu \mathrm{g} / \mathrm{kg}$ of animal weight orally using a metal catheter for 30 days $(n=10)$. The animals of the control group $(n=10)$ were injected with an equivalent volume of distilled water for 30 days. $\mathrm{C}_{60}$ FAS was administered at doses of $0.5(n=10)$ and $1 \mathrm{mg} / \mathrm{kg}$ of animal weight $(n=10)$ immediately after administration of the herbicide for 30 days. Measurements of the studied parameters (see below) in all groups were performed on the $31^{\text {st }}$ day after the start of the experiment.

It should be noted that the use of selected doses of $\mathrm{C}_{60} \mathrm{FAS}$ are based on previous experimentally established data, which showed a high protective effect of water-soluble $\mathrm{C}_{60}$ fullerenes $[13,14,19]$. Additionally, it should be noted that the doses of $\mathrm{C}_{60}$ fullerene used in our experiments are significantly lower than the $\mathrm{LD}_{50}$ value, which was $600 \mathrm{mg} / \mathrm{kg}$ body weight when administered orally to rats [40] and $721 \mathrm{mg} / \mathrm{kg}$ when administered intraperitoneally to mice [25].

Anesthesia of animals was performed by intraperitoneal administration of nembutal $(40 \mathrm{mg} / \mathrm{kg})$. Preparation of the experiment included the cannulation (a. carotis communis sinistra) for the therapeutic administration of the drug and pressure measurement, tracheotomy and laminectomy at lumbar spinal cord level. Muscle soleus of rat was released 
from the surrounding tissues. Its tendon was cut across in distal part, which was connected to the force sensors. For modulated stimulation of efferents, the ventral roots were cut at the points of their exit from the spinal cord. Stimulation of efferents was performed by electrical pulses lasting $2 \mathrm{~ms}$, generated by the generator, through platinum electrodes. The control of the external load on the muscle was performed using a system of mechanical stimulators. Perturbation of the load was carried out by a linear electromagnetic motor [41].

The choice of muscle soleus for this study is due to the fact that this muscle contains the maximum number of slow fibers, which is important for accurate and high-quality fixation of fast-acting processes, occurring in the anterior front of the tetanus, in pathology.

To induce muscle contraction, a stimulation signal with a frequency of $50 \mathrm{~Hz}$ and a duration of $5 \mathrm{~s}$ was used without a relaxation period. The total duration of stimulation was $1500 \mathrm{~s}$. The current strength, at which the muscle began to contract, was considered a threshold, and further stimulation was performed with a current strength of 1.3-1.4 thresholds.

To record the force of skeletal muscle contraction, we used the original strain gauge that consists of force and length sensors, a synchronous pulse generator and a thermal control system [13].

In the process of analyzing the obtained results, the following parameter was used: the integrated power of muscle contraction (calculated area under the force curve), which is an indicator of the overall performance of the muscle with the applied stimulation pools. The development of muscle contractile activity was assessed by calculating the time of the decrease in the force response by $50 \%$ and $25 \%$ of the initial values during stimulation. We also analyzed the time to reach the maximum value of the muscle contraction force and the delay in the onset of the muscle response.

The level of enzymes content in the blood of experimental animals (creatinine, CPK, LA, LDH, TBARS, $\mathrm{H}_{2} \mathrm{O}_{2}$, GSH and CAT), as marker of muscle injury [42], was determined using clinical diagnostic equipment-a haemoanalyzer [13].

Statistical processing of results was performed by methods of variation statistics using software Original 9.4. We conducted at least six repetitions for each measurement. Data are expressed as the means \pm SEM for each group. The differences among experimental groups were detected by one-way ANOVA followed by Bonferroni's multiple comparison test. Values of $p<0.05$ were considered significant.

\section{Conclusions}

The obtained results indicate that the therapeutic administration of water-soluble $\mathrm{C}_{60}$ fullerenes at a dose of $0.5 \mathrm{mg} / \mathrm{kg}$ reduces the degree of pathological changes in rats caused by chronic glyphosate intoxication by $40-45 \%$. Increasing the dose of water-soluble $\mathrm{C}_{60}$ fullerenes to $1 \mathrm{mg} / \mathrm{kg}$ increases the therapeutic effect by $55-65 \%$, normalizing the studied biomechanical and biochemical parameters. Considering the fact that poisoning with glyphosate compounds has a lethality of up to $20 \%$ and there is currently no antidote to them, and the basis for the treatment of systemic toxicity is deactivation and aggressive supportive therapy [34], the proposed $\mathrm{C}_{60}$ fullerene therapy of this type of intoxication opens up new prospects for clinical trials.

Author Contributions: Biomechanical analysis, D.N., O.A. and V.S.; biochemical analysis, S.P., O.V. and K.B.; sample preparation, U.R. and P.S.; characterization of the samples, S.K. and Y.P.; coordination the research work, analysis of the data and preparing of the manuscript, Y.P. All authors have read and agreed to the published version of the manuscript.

Funding: This research received no external funding.

Institutional Review Board Statement: The study protocol was approved by the bioethics committee of Taras Shevchenko National University of Kyiv in accordance with the rules of the European Convention for the Protection of Vertebrate Animals Used for Experimental and Other Scientific Purposes and the norms of biomedical ethics in accordance with the Law Of Ukraine №3446-IV 21.02.2006, Kyiv, on the Protection of Animals from Cruelty during medical and biological research. 
Informed Consent Statement: Not applicable.

Data Availability Statement: Not applicable.

Acknowledgments: This research was supported by the Ministry of Education and Science of Ukraine. We acknowledge support for the publication costs by the Open Access Publication Fund of the Technische Universität Ilmenau.

Conflicts of Interest: Authors declare that they have no conflict of interest.

\section{References}

1. Benbrook, C.M. Trends in glyphosate herbicide use in the United States and globally. Environ. Sci. Eur. 2016, 28, 1-15. [CrossRef] [PubMed]

2. Van Bruggen, A.H.C.; He, M.M.; Shin, K.; Mai, V.; Jeong, K.C.; Finckh, M.R.; Morris, J.G., Jr. Environmental and health effects of the herbicide glyphosate. Sci. Total Environ. 2018, 616-617, 255-268. [CrossRef] [PubMed]

3. Portier, C.J. A comprehensive analysis of the animal carcinogenicity data for glyphosate from chronic exposure rodent carcinogenicity studies. Environ. Health 2020, 19, 18. [CrossRef] [PubMed]

4. Chłopecka, M.; Mendel, M.; Dzieka, N.; Wojciech, K. Glyphosate affects the spontaneous motoric activity of intestine at very low doses-In vitro study. Pestic. Biochem. Physiol. 2014, 113, 25-30. [CrossRef] [PubMed]

5. Zhidenko, A.A.; Bibchuk, E.V.; Barbukho, E.V. Effect of glyphosate on the energy exchange in carp organs. Ukr. Kyi Biokhimichnyi Zhurnal 2013, 85, 22-30. [CrossRef] [PubMed]

6. Lopes, F.M.; Caldas, S.S.; Primel, E.G.; da Rosa, C.E. Glyphosate adversely affects Danio rerio males: Acetylcholinesterase modulation and oxidative stress. Zebrafish 2017, 14, 97-105. [CrossRef] [PubMed]

7. Dornelles, M.F.; Oliveira, G.T. Toxicity of atrazine, glyphosate, and quinclorac in bullfrog tadpoles exposed to concentrations below legal limits. Environ. Sci. Pollut. Res. Int. 2016, 23, 1610-1620. [CrossRef] [PubMed]

8. Bradberry, S.M.; Proudfoot, A.T.; Vale, J.A. Glyphosate poisoning. Toxicol. Rev. 2004, 23, 159-167. [CrossRef]

9. Cattaneo, R.; Clasen, B.; Loro, V.L.; de Menezes, C.C.; Pretto, A.; Baldisserotto, B.; Santi, A.; de Avila, L.A. Toxicological responses of Cyprinus carpio exposed to a commercial formulation containing glyphosate. Bull. Environ. Contam. Toxicol. 2011, 87, 597-602. [CrossRef]

10. Krusic, P.J.; Wasserman, E.; Keizer, P.N.; Morton, J.R.; Preston, K.F. Radical reactions of C60. Science 1991, 254, 1183-1185. [CrossRef]

11. Ferreira, C.A.; Ni, D.; Rosenkrans, Z.T.; Cai, W. Scavenging of reactive oxygen and nitrogen species with nanomaterials. Nano Res. 2018, 11, 4955-4984. [CrossRef]

12. Halenova, T.; Raksha, N.; Savchuk, O.; Ostapchenko, L.; Prylutskyy, Y.; Ritter, U.; Scharff, P. Evaluation of the biocompatibility of water-soluble pristine $\mathrm{C}_{60}$ fullerenes in rabbit. BioNanoScience 2020, 10, 721-730. [CrossRef]

13. Nozdrenko, D.M.; Zavodovsky, D.O.; Matvienko, T.Y.; Zay, S.Y.; Bogutska, K.I.; Prylutskyy, Y.I.; Ritter, U.; Scharff, P. C 60 fullerene as promising therapeutic agent for the prevention and correction of functioning skeletal muscle at ischemic injury. Nanoscale Res. Lett. 2017, 12, 1-9. [CrossRef]

14. Vereshchaka, I.V.; Bulgakova, N.V.; Maznychenko, A.V.; Gonchar, O.O.; Prylutskyy, Yu.I.; Ritter, U.; Moska, W.; Tomiak, T.; Nozdrenko, D.M.; Mishchenko, I.V.; et al. $\mathrm{C}_{60}$ fullerenes diminish the muscle fatigue in rats comparable to N-acetylcysteine or $\beta$-alanine. Front. Physiol. 2018, 9, 517. [CrossRef]

15. Halenova, T.I.; Vareniuk, I.M.; Roslova, N.M.; Dzerzhynsky, M.E.; Savchuk, O.M.; Ostapchenko, L.I.; Prylutskyy, Yu.I.; Ritter, U.; Scharff, P. Hepatoprotective effect of orally applied water-soluble pristine $\mathrm{C}_{60}$ fullerene against CCl4-induced acute liver injury in rats. RSC Adv. 2016, 6, 100046-100055. [CrossRef]

16. Lynchak, O.V.; Prylutskyy, Yu.I.; Rybalchenko, V.K.; Kyzyma, O.A.; Soloviov, D.; Kostjukov, V.V.; Evstigneev, M.P.; Ritter, U.; Scharff, P. Comparative analysis of the antineoplastic activity of $\mathrm{C}_{60}$ fullerene with 5-fluorouracil and pyrrole derivative in vivo. Nanoscale Res. Lett. 2017, 12, 1-6. [CrossRef]

17. Halenova, T.I.; Raksha, N.G.; Vovk, T.B.; Savchuk, O.M.; Ostapchenko, L.I.; Prylutskyy, Yu.I.; Kyzyma, O.A.; Ritter, U.; Scharff, P. Effect of $\mathrm{C}_{60}$ fullerene nanoparticles on the diet-induced obesity in rats. Int. J. Obes. 2018, 42, 1987-1998. [CrossRef]

18. Kuznietsova, H.M.; Lynchak, O.V.; Dziubenko, N.V.; Osetskyi, V.L.; Ogloblya, O.V.; Prylutskyy, Yu.I.; Rybalchenko, V.K.; Ritter, U.; Scharff, P. Water-soluble $\mathrm{C}_{60}$ fullerenes reduce manifestations of acute cholangitis in rats. Appl. Nanosci. 2019, 9, 601-608. [CrossRef]

19. Maznychenko, A.V.; Mankivska, O.P.; Sokolowska, I.V.; Kopyak, B.S.; Tomiak, T.; Bulgakova, N.V.; Gonchar, O.O.; Prylutskyy, Y.I.; Ritter, U.; Mishchenko, I.V.; et al. $\mathrm{C}_{60}$ fullerenes increase the intensity of rotational movements in non-anesthetized hemiparkinsonic rats. Acta Neurobiol. Exp. 2020, 80, 32-37.

20. Kuznietsova, H.; Dziubenko, N.; Herheliuk, T.; Prylutskyy, Yu.; Tauscher, E.; Ritter, U.; Scharff, P. Water-soluble pristine C 60 fullerene inhibits liver alterations associated with hepatocellular carcinoma in rat. Pharmaceutics 2020, 12, 794. [CrossRef]

21. Lyon, D.Y.; Adams, L.K.; Falkner, J.C.; Alvarezt, P.J. Antibacterial activity of fullerene water suspensions: Effects of preparation method and particle size. Environ. Sci. Technol. 2006, 40, 4360-4366. [CrossRef] 
22. Zhang, B.; Bian, W.; Pal, A.; He, Y. Macrophage apoptosis induced by aqueous $\mathrm{C}_{60}$ aggregates changing the mitochondrial membrane potential. Environ. Toxicol. Pharmacol. 2015, 39, 237-246. [CrossRef]

23. Sayers, B.C.; Germolec, D.R.; Walker, N.J.; Shipkowski, K.A.; Stout, M.D.; Cesta, M.F.; Roycroft, J.H.; White, K.L.; Baker, G.L.; Dill, J.A.; et al. Respiratory toxicity and immunotoxicity evaluations of microparticle and nanoparticle $\mathrm{C}_{60}$ fullerene aggregates in mice and rats following nose-only inhalation for 13 weeks. Nanotoxicology 2016, 10, 1458-1468. [CrossRef]

24. Melnyk, M.I.; Ivanova, I.V.; Dryn, D.O.; Prylutskyy, Yu.I.; Hurmach, V.V.; Platonov, M.; Al Kury, L.T.; Ritter, U.; Soloviev, A.I.; Zholos, A.V. $\mathrm{C}_{60}$ fullerenes selectively inhibit BKCa but not $\mathrm{Kv}$ channels in pulmonary artery smooth muscle cells. Nanomed. Nanotechnol. Biol. Med. 2019, 19, 1-11. [CrossRef] [PubMed]

25. Prylutska, S.V.; Grebinyk, A.G.; Lynchak, O.V.; Byelinska, I.V.; Cherepanov, V.V.; Tauscher, E.; Matyshevska, O.P.; Prylutskyy, Yu.I.; Rybalchenko, V.K.; Ritter, U.; et al. In vitro and in vivo toxicity of pristine $\mathrm{C}_{60}$ fullerene aqueous colloid solution. Fuller. Nanotub. Carbon Nanostructures 2019, 27, 715-728. [CrossRef]

26. Schuetze, C.; Ritter, U.; Scharff, P.; Bychko, A.; Prylutska, S.; Rybalchenko, V.; Prylutskyy, Yu. Interaction of N-fluorescein-5isothiocyanate pyrrolidine- $\mathrm{C}_{60}$ compound with a model bimolecular lipid membrane. Mater. Sci. Eng. C 2011, 31, 1148-1150. [CrossRef]

27. Ritter, U.; Prylutskyy, Yu.I.; Evstigneev, M.P.; Davidenko, N.A.; Cherepanov, V.V.; Senenko, A.I.; Marchenko, O.A.; Naumovets, A.G. Structural features of highly stable reproducible $\mathrm{C}_{60}$ fullerene aqueous colloid solution probed by various techniques. Fuller. Nanotub. Carbon Nanostructures 2015, 23, 530-534. [CrossRef]

28. Skamrova, G.B.; Laponogov, I.; Buchelnikov, A.S.; Shckorbatov, Y.G.; Prylutska, S.V.; Ritter, U.; Prylutskyy, Y.I.; Evstigneev, M.P. Interceptor effect of $C_{60}$ fullerene on the in vitro action of aromatic drug molecules. Eur. Biophys. J. 2014, 43, 265-276. [CrossRef]

29. Menéndez-Helman, R.J.; Miranda, A.L.; Dos Santos Afonso, M.; Salibián, A. Subcellular energy balance of Odontesthes bonariensis exposed to a glyphosate-based herbicide. Ecotoxicol. Environ. Saf. 2015, 114, 157-163. [CrossRef]

30. Gallegos, C.E.; Bartos, M.; Bras, C.; Gumilar, F.; Antonelli, M.C.; Minetti, A. Exposure to a glyphosate-based herbicide during pregnancy and lactation induces neurobehavioral alterations in rat offspring. Neurotoxicology 2016, 53, 20-28. [CrossRef]

31. Nozdrenko, D.M.; Miroshnychenko, M.S.; Soroca, V.M.; Korchinska, L.V.; Zavodovskiy, D.O. The effect of chlorpyrifos upon ATPase activity of sarcoplasmic reticulum and biomechanics of skeletal muscle contraction. Ukr. Biochem. J. 2016, 88, 82-88. [CrossRef]

32. Nozdrenko, D.M.; Abramchuk, O.M.; Soroca, V.M.; Miroshnichenko, N.S. Aluminum chloride effect on Ca2+,Mg2+-ATPase activity and dynamic parameters of skeletal muscle contraction. Ukr. Biochem. J. 2015, 87, 38-45. [CrossRef]

33. Nozdrenko, D.M.; Korchinska, L.V.; Soroca, V.M. Activity of $\mathrm{Ca}(2+), \mathrm{Mg}(2+)$-ATPase of sarcoplasmic reticulum and contraction strength of the frog skeletal muscles under the effect of organophosphorus insecticides. Ukr. Biochem. J. 2015, 87, 63-69. [CrossRef]

34. Thakur, D.S.; Khot, R.; Joshi, P.P.; Pandharipande, M.; Nagpure, K. Glyphosate poisoning with acute pulmonary edema. Toxicol. Int. 2014, 21, 328-330. [CrossRef]

35. Gonchar, O.O.; Maznychenko, A.V.; Bulgakova, N.V.; Vereshchaka, I.V.; Tomiak, T.; Ritter, U.; Prylutskyy, Yu.I.; Mankovska, I.M.; Kostyukov, A.I. $\mathrm{C}_{60}$ fullerene prevents restraint stress-induced oxidative disorders in rat tissues: Possible involvement of the Nrf2/ARE-antioxidant pathway. Oxid. Med. Cell. Longev. 2018, 2018, 2518676. [CrossRef]

36. Stur, E.; Aristizabal-Pachon, A.F.; Peronni, K.C.; Agostini, L.P.; Waigel, S.; Chariker, J.; Miller, D.M.; Thomas, S.D.; Rezzoug, F.; DeTogni, R.S.; et al. Glyphosate-based herbicides at low doses affect canonical pathways in estrogen positive and negative breast cancer cell lines. PLoS ONE 2019, 14, e0219610. [CrossRef]

37. Russ, K.A.; Elvati, P.; Parsonage, T.L.; Dews, A.; Jarvis, J.A.; Ray, M.; Schneider, B.; Smith, P.J.S.; Williamson, P.T.F.; Violi, A.; et al. $\mathrm{C}_{60}$ fullerene localization and membrane interactions in RAW 264.7 immortalized mouse macrophages. Nanoscale 2016, 8 , 4134-4144. [CrossRef]

38. Eswaran, S.V. Water soluble nanocarbon materials: A panacea for all? Curr. Sci. 2018, 114, 1846-1850. [CrossRef]

39. Scharff, P.; Carta-Abelmann, L.; Siegmund, C.; Matyshevska, O.P.; Prylutska, S.V.; Koval, T.V.; Golub, A.A.; Yashchuk, V.M.; Kushnir, K.M.; Prylutskyy, Yu.I. Effect of X-ray and UV irradiation of the $\mathrm{C}_{60}$ fullerene aqueous solution on biological samples. Carbon 2004, 42, 1199-1201. [CrossRef]

40. Gharbi, N.; Pressac, M.; Hadchouel, M.; Szwarc, H.; Wilson, S.R.; Moussa, F. Fullerene is a powerful antioxidant in vivo with no acute or subacute toxicity. Nano Lett. 2005, 5, 2578-2585. [CrossRef]

41. Nozdrenko, D.N.; Berehovyi, S.M.; Nikitina, N.S.; Stepanova, L.I.; Beregova, T.V.; Ostapchenko, L.I. The influence of complex drug cocarnit on the nerve conduction velocity in nerve tibialis of rats with diabetic polyneuropathy. Biomed. Res. 2018, $29,3629$.

42. Brancaccio, P.; Lippi, G.; Maffulli, N. Biochemical markers of muscular damage. Clin. Chem. Lab. Med. 2010, 48, 757-767. [CrossRef] 